\title{
Synthesis, Characterization, and Osteoblastic Cell Culture of Poly(L-co-D,L-lactide-co-trimethylene carbonate) Scaffolds
}

\author{
André Dutra Messias, ${ }^{1,2}$ Kelly Fernanda Martins, ${ }^{2,3}$ \\ Adriana Cristina Motta, ${ }^{2}$ and Eliana Aparecida de Rezende Duek ${ }^{1,2,3}$ \\ ${ }^{1}$ Department of Materials Engineering, Faculty of Mechanical Engineering, State University of Campinas, \\ Rua Mendeleyev 200, 13083-860 Campinas, SP, Brazil \\ ${ }^{2}$ Laboratory of Biomaterials, Faculty of Medical Sciences and Health, Pontifical Catholic University of São Paulo, \\ Rua Joubert Wey 290, 18030-070 Sorocaba, SP, Brazil \\ ${ }^{3}$ Federal University of Sao Carlos, Rodovia João Leme dos Santos, Km 110, SP-264, Itinga, 18052-780 Sorocaba, SP, Brazil
}

Correspondence should be addressed to André Dutra Messias; andre_messias@ymail.com

Received 23 October 2013; Revised 3 June 2014; Accepted 4 June 2014; Published 25 June 2014

Academic Editor: Feng Huei Lin

Copyright (C) 2014 André Dutra Messias et al. This is an open access article distributed under the Creative Commons Attribution License, which permits unrestricted use, distribution, and reproduction in any medium, provided the original work is properly cited.

\begin{abstract}
Lactide-based polymers have been widely investigated as materials for tissue engineering. However, characteristics such as low flexibility and elongation tend to limit particular applications, although these can be enhanced by adding plasticizers such as trimethylene carbonate (TMC) to the polymer chain of the copolymer poly(L-lactide-co-D,L-lactide) (PLDLA). The aim of this work was to synthesize and characterize a terpolymer of L-lactide, D,L-lactide, and TMC. The polymers were synthesized from $30 \%$ TMC by bulk polymerization and resulted in an average molar mass $>10^{5} \mathrm{~g} / \mathrm{mol}$. Thermal investigation of PLDLA-TMC showed a decrease in the glass transition and onset temperatures compared to PLDLA. PLDLA-TMC scaffolds stimulated the proliferation and normal phenotypic manifestations of cultured osteoblasts. These results show that it was possible to produce a terpolymer from L-lactide, D,L-lactide, and TMC. Scaffolds of this terpolymer had important characteristics that could be useful for applications in bone tissue engineering.
\end{abstract}

\section{Introduction}

Bone has a limited capacity for regeneration, especially in cases involving large losses as a result of complicated fractures caused by trauma, disease, birth defects, bone tumor removal, joint replacement, spinal fusion, or periodontal diseases. Bone loss is a major challenge for modern medicine, particularly since current techniques, such as metallic implants and autologous bone grafts, have significant drawbacks. There is therefore a need to develop novel therapeutic approaches such as bone tissue engineering $[1,2]$.

Tissue engineering seeks to create an alternative means of repairing bone injuries by combining a scaffold, cells, and growth factors to produce tissue substitutes capable of restoring or replacing lost tissues and organs. The approaches used include cell therapies, induction of tissue/organ regeneration by biologically active molecules, and the transplantation of tissues grown in vitro $[2,3]$. An underlying principle in this approach is that biomaterial or cell-biomaterial constructs degrade concomitantly with tissue regeneration.

$\operatorname{Poly}(\alpha$-hydroxyacids) are biodegradable, resorbable materials with good biocompatibility and these features make them preferred candidates for tissue engineering. The lactide monomers have different chiral molecules. Among lactidederived polymers, only poly(L-lactide) and poly(D,L-lactide) have been extensively investigated as biomaterials. The biological properties of the copolymer poly(L-co-D,L lactide) (PLDLA) remain poorly known whereas poly(L-lactide) (PLLA) is a semicrystalline polymer with a high modulus and strength. PLLA is known for its increasing crystallinity during degradation which can generate an intense inflammatory response [4]. In contrast, poly(D,L-lactide) (PDLLA) is an amorphous polymer characterized by the random distribution of the two isomeric forms along the polymer 
chain [5]. PLDLA is also amorphous and has mechanical features similar to those of PLLA without the inconvenience of long degradation times and high crystallinity.

The brittle nature of poly(lactides) requires modification in order to be useful as biomedical materials [6]. The need for biodegradable elastomeric polymers for medical implants and porous scaffolds in tissue engineering has been documented in recent years [7-9]. The suitability of poly trimethylene carbonate (TMC) for the preparation of biomedical implants has also been evaluated [10]. Poly(TMC) has a very low modulus and tensile strength and its poor mechanical properties have discouraged any practical application other than as a component of copolymers and blends. Poly(TMC) has been used as a softening unit in stiff and brittle polymers such as lactide $[7,11,12]$ and glycolide [13].

Scaffolds are implants or injections that are used to deliver cells, drugs, and genes into the body. Different forms of polymeric scaffolds for cell/drug delivery are available, for example, typical three-dimensional porous matrices, nanofiber matrices, thermosensitive sol-gel transition hydrogels, and a porous microsphere. A scaffold provides a suitable substrate for cell attachment, cell proliferation, differentiated function, and cell migration [14].

Porous bioresorbable polymers have been widely used as scaffolds in tissue engineering. Macroporous structures are desirable in many cases to facilitate cell seeding, infiltration of fluids, vascularization, and tissue ingrowth. In this context, several techniques have been developed to create porous scaffolds, including solvent casting/particulate leaching, fiber bonding, gas foaming, phase inversion, and solvent removal by freeze-drying. The morphology and properties of the resulting scaffolds depend largely on the fabrication process used [15].

Polymeric scaffolds should be designed to facilitate cell distribution and guide tissue regeneration in three dimensions [16]. Among the different methods for producing scaffolds, solvent casting followed by precipitation or particulate leaching is one of the most straightforward methods $[17,18]$. Particulate leaching is a general procedure that is used to obtain porous scaffolds in solvent casting methods $[19,20]$.

In this study, scaffolds of PLDLA and PLDLA-TMC were prepared by solvent casting/particulate leaching using saccharose crystals as the porogen. The copolymers synthesized were characterized by physical and chemical methods and the thermal properties of the scaffolds were investigated. The usefulness of the scaffolds for stimulating osteoblast adhesion and proliferation in vitro was also assessed.

\section{Materials and Method}

2.1. Poly(L-co-D,L-lactide-co-trimethylene carbonate) Synthesis. Polymerization was carried out using L-lactide (Purasorb L, Purac, Netherlands), D,L-lactide (Purasorb DL, Purac), and trimethylene carbonate (TMC, 1,3-dioxane-2one; Boehringer Ingelheim Pharma, Germany) in $70: 30: 0$ and 50:20:30 monomer ratios catalyzed by $\mathrm{Sn}(\mathrm{Oct})_{2}$ at $130^{\circ} \mathrm{C}$ for $48 \mathrm{~h}$ in a vacuum ampoule (INPI patent requisition, protocol number 020110049277). The polymers were subsequently purified by dissolution in chloroform and precipitation in methanol.

\subsection{Physicochemical Characterization of the Synthesized Polymer}

2.2.1. Nuclear Magnetic Resonance (NMR). Nuclear magnetic resonance (NMR) spectra were obtained with a Bruker 250 spectrometer operated at $300 \mathrm{MHz}$ and $75 \mathrm{MHz}$ for ${ }^{1} \mathrm{H}$ and ${ }^{13} \mathrm{C}$, respectively, at room temperature. The polymer samples $(10 \% \mathrm{w} / \mathrm{v})$ were dissolved in deuterated chloroform $\left(\mathrm{CDCl}_{3}\right)$ and tetramethylsilane was used as the reference standard.

2.2.2. Fourier Transform Infrared (FTIR) Spectrometry. Fourier transform infrared (FTIR) spectrometry was carried out using a Perkin Elmer FT-IR Spectrum One spectrometer in the range of $4000-650 \mathrm{~cm}^{-1}$ after casting the polymer from chloroform solution onto sodium chlorite pellets.

2.2.3. Gel Permeation Chromatography (GPC). Gel permeation chromatography (GPC) analyses were carried out using a Waters instrument (1525 binary HPLC pump and 2414 refractive index detector, Waters Corporation, USA) equipped with Waters Styragel columns (HR 4E and HR 5E). Tetrahydrofuran was used as the mobile phase at a flow rate of $1 \mathrm{~mL} / \mathrm{min}$. The columns and detector were maintained at $30^{\circ} \mathrm{C}$ and $40^{\circ} \mathrm{C}$, respectively.

\subsection{Scaffold Fabrication, Morphology, and Thermal Properties}

2.3.1. Scaffold Fabrication. The polymer scaffolds were prepared by the solvent casting/particulate leaching method. Initially, the polymer was dissolved in chloroform $(10 \% \mathrm{w} / \mathrm{v})$ for $4 \mathrm{~h}$. After complete dissolution, a $70 \%(\mathrm{w} / \mathrm{v})$ solution of ground, sieved sucrose crystals $(>250 \mu \mathrm{m})$ was added. The mixture was then cast in silicone molds with cylindrical cavities (7 $\mathrm{mm}$ in diameter and $10 \mathrm{~mm}$ high) and the solvent was allowed to evaporate overnight at room temperature. Sucrose particles were removed by immersion in a $1 \%(\mathrm{w} / \mathrm{v})$ aqueous solution of polyvinyl alcohol in order to reduce the surface tension between the polymer and water. Finally, the scaffolds were dried in a vacuum and sliced to form disks $\sim 4 \mathrm{~mm}$ high.

2.3.2. Scanning Electron Microscopy (SEM). Morphological analysis of the scaffolds was carried out by scanning electron microscopy (SEM) using a JEOL JXA-840A scanning electron microscope after gold coating (Balzer SCD 050) of the samples. Some samples were immersed in liquid nitrogen and fractured in order to examine the internal structure of the scaffold.

2.3.3. Scanning Differential Calorimetry (DSC). Scanning differential calorimetry (DSC) measurements were carried out on a DSC 2920 thermal analyzer (TA Instruments, USA). Polymeric samples were hermetically sealed in aluminum 
pans and heated at $200^{\circ} \mathrm{C}$ to destroy the thermal history of the polymers. Subsequently, the samples were exposed to temperatures ranging from $-50^{\circ} \mathrm{C}$ to $200^{\circ} \mathrm{C}$ at increments of $10^{\circ} \mathrm{C} \mathrm{min}{ }^{-1}$, in an inert nitrogen atmosphere flushed at $5 \mathrm{~mL} \mathrm{~min}^{-1}$.

2.3.4. Thermogravimetric Analysis (TGA). The thermal stability of the scaffolds was tested in an STA 409C thermogravimetric analyzer (Netzsch) in which the samples were heated at $10^{\circ} \mathrm{C} \mathrm{m^{-1 }}$ up to $500^{\circ} \mathrm{C}$, in an inert argon atmosphere.

\subsection{Osteoblast Cell Culture on Scaffolds}

2.4.1. Cell Culture. Human osteoblast-like SaOS-2 cells were purchased from the Rio de Janeiro Cell Bank (Rio de Janeiro, RJ, Brazil) and cultured in McCoy's 5A modified medium (CULTILAB, Brazil) containing L-glutamine, HEPES, 15\% fetal bovine serum (FBS-CULTILAB, Brazil), $50 \mathrm{mg}$ of getamicin/L (Invitrogen), and $2.5 \mathrm{mg}$ of amphotericin $\mathrm{B} / \mathrm{L}$ (Invitrogen) in a humidified $95 \%$ air $/ 5 \% \mathrm{CO}_{2}$ incubator, at $37^{\circ} \mathrm{C}$. The medium was changed every 3-4 days. Cells were detached by treatment with a trypsin/EDTA solution (CULTILAB, Brazil).

The scaffolds were sterilized by immersion in $70 \%$ ethanol for $1 \mathrm{~h}$ and repeatedly washed with deionized water. Before cell culture, sterilized scaffolds were maintained in McCoy's $5 \mathrm{~A}$ medium for $\sim 24 \mathrm{~h}$.

A cell suspension $\left(1 \times 10^{4}\right.$ cells/well in $200 \mu \mathrm{L}$ of growth medium) was seeded onto scaffolds of PLDLA-TMC and PLDLA in 96-well plates (TPP, Switzerland) and cultured for $1,3,7$, and 14 days. Control cells were cultured in wells without scaffolds. The long-term culture clarifies how the scaffolds can sustain the cell proliferation and also allows the observation of the cell differentiation.

2.4.2. MTT Assay. To evaluate the mitochondrial activity of the seeded cells, that is, cell viability on the scaffolds during culture, the samples and controls were washed 2-3 times with McCoy' $5 \mathrm{~A}$ medium without serum and then incubated with $200 \mu \mathrm{L}$ of 3-(4,5-dimethyl-2-thiazolyl)-2,5-diphenyl$2 \mathrm{H}$-tetrazolium bromide (MTT-Sigma-Aldrich) in McCoy's medium $\left(0.5 \mathrm{mg} \mathrm{mL}^{-1}\right)$. The plates were incubated for $4 \mathrm{~h}$ in a cell incubator at $37^{\circ} \mathrm{C}$, after which the MTT solution was replaced with $200 \mu \mathrm{L}$ of dimethylsulphoxide (DMSOSigma-Aldrich). After $10 \mathrm{~min}, 100 \mu \mathrm{L}$ aliquots were transferred to empty wells and the absorbances were measured in a microplate reader (Elx-800-UV, Bio-Tek Instruments) at $570 \mathrm{~nm}$ and $650 \mathrm{~nm}$.

2.4.3. ALP Assay. Alkaline phosphatase (ALP) produced by SaOS-2 was quantified as an osteoblast marker using an ALP kit (Labtest, Brazil). Briefly, $10 \mu \mathrm{L}$ aliquots of culture supernatant were collected and added to $100 \mu \mathrm{L}$ of $p$-nitrophenol phosphate solution (12 mM p-nitrophenol phosphate, $10 \mathrm{mM}$ phenol, and 1.6 mM EDTA buffered to $\mathrm{pH} 10.4,0.96 \mathrm{mM}$ zinc sulfate, $2 \mathrm{mM}$ magnesium acetate, and $6.4 \mathrm{mM}$ sodium azide). The reagent was run for $2 \mathrm{~min}$ at $37^{\circ} \mathrm{C}$ and the changes

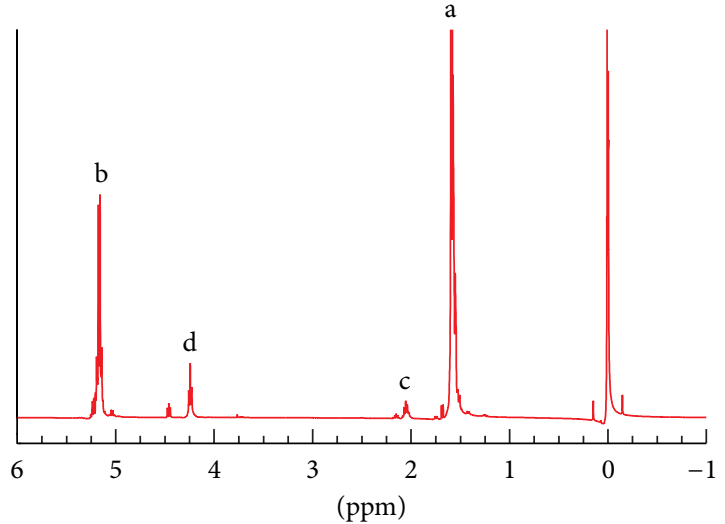

- PLDLA-TMC

Figure 1: ${ }^{1} \mathrm{H}$ NMR spectra of PLDLA-TMC.

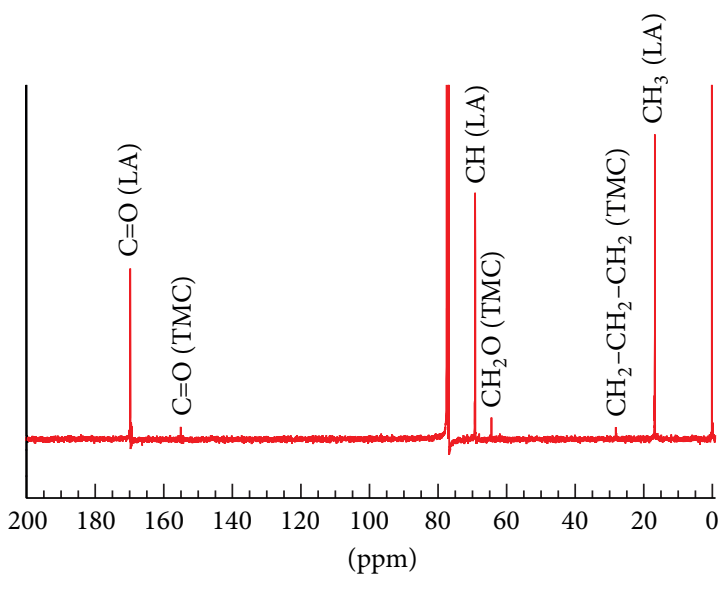

— PLDLA-TMC

Figure $2:{ }^{13} \mathrm{C}$ NMR spectrum of PLDLA-TMC.

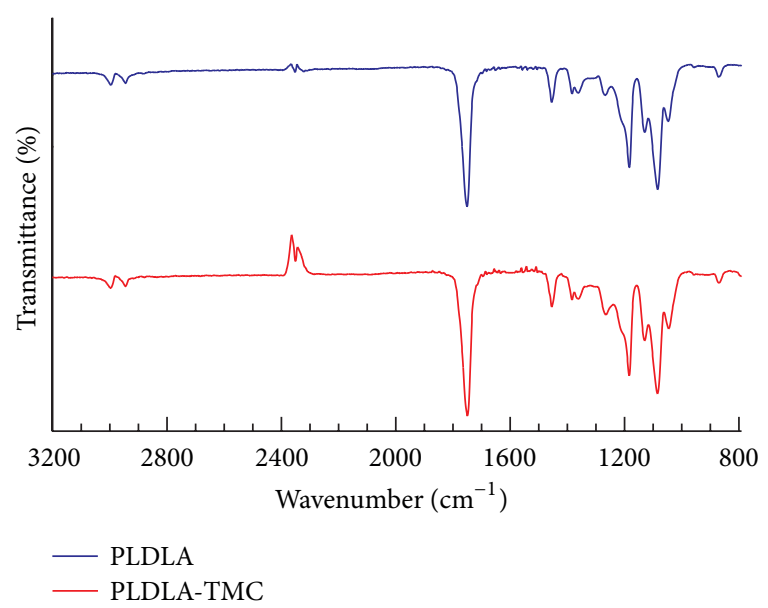

Figure 3: FT-IR spectra of PLDLA and PLDLA-TMC. 


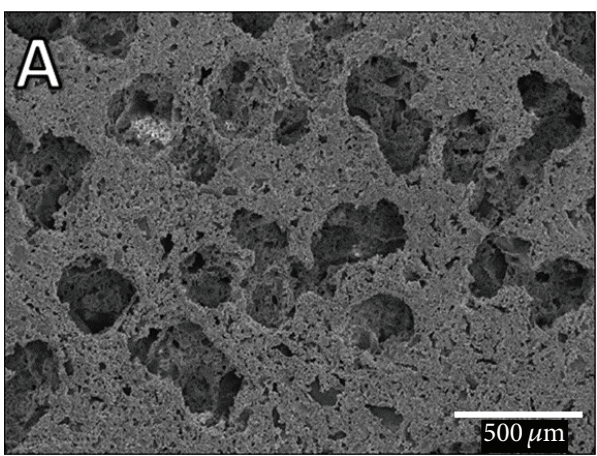

(a)

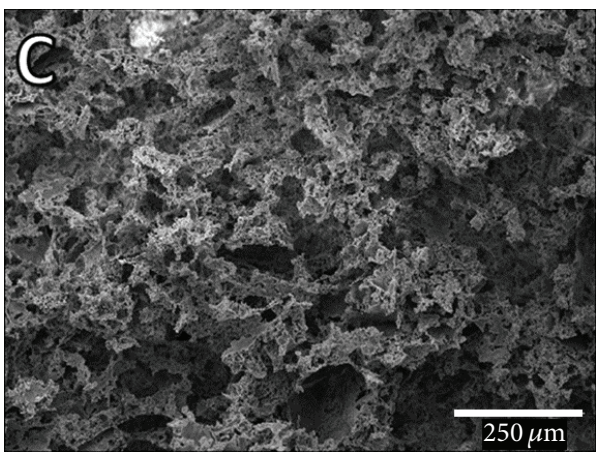

(c)

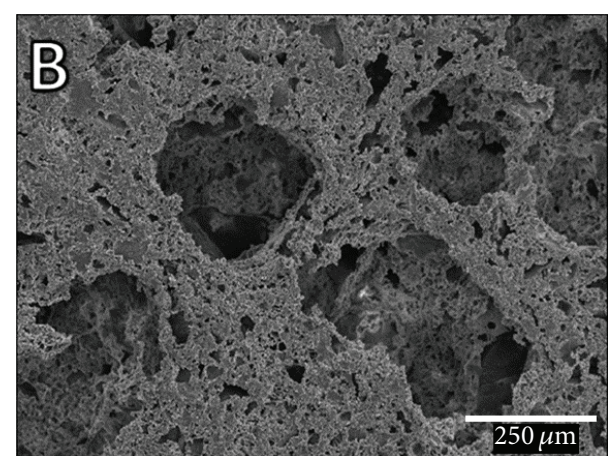

(b)

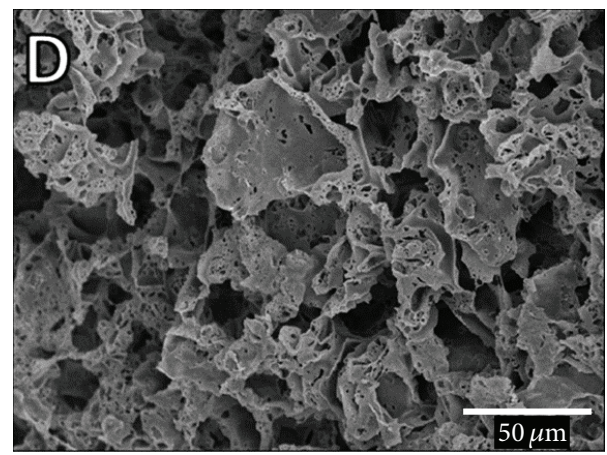

(d)

FIGURE 4: SEM of PLDLA-TMC scaffolds showing the external $(a, b)$ and inner (c, d) surfaces. Inner views of the scaffolds were obtained after cryofracture.

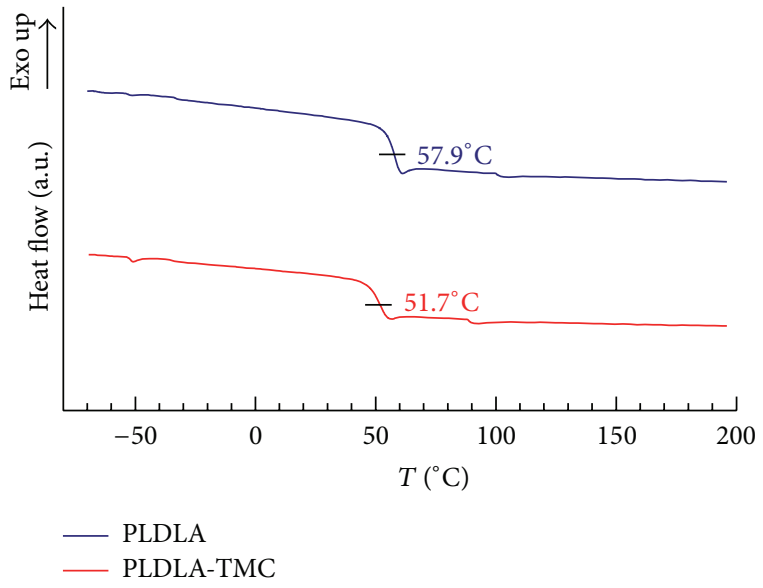

FIGURE 5: DSC thermograms showing the glass transition temperature of PLDLA and PLDLA-TMC scaffolds.

in absorbance were measured in a microplate reader at $415 \mathrm{~nm}$ and $650 \mathrm{~nm}$.

\section{Results and Discussion}

3.1. Physicochemical Characterization of the Synthesized Polymer. Poly(L-co-D,L-lactide-co-trimethylene carbonate) was synthesized by bulk polymerization via ring-opening of cyclic dimer monomers at $130^{\circ} \mathrm{C}$ for $48 \mathrm{~h}$ in a vacuum atmosphere.
TABLE 1: Molar mass of terpolymer.

\begin{tabular}{lccc}
\hline \% TMC & $\mathrm{Mw}(\mathrm{g} / \mathrm{mol})$ & $\mathrm{Mn}(\mathrm{g} / \mathrm{mol})$ & PDI \\
\hline $20 \%$ TMC & 127.630 & 69.694 & 1,7 \\
$30 \%$ TMC & 126.577 & 60.451 & 2,0 \\
\hline
\end{tabular}

$\mathrm{Mw}=$ weight average molecular weight; $\mathrm{Mn}=$ number average molecular weight; PDI = polydispersity index .

Table 1 shows molar mass of terpolymer measured by GPC. The catalyst used was stannous octoate $\left(\mathrm{Sn}(\mathrm{Oct})_{2}\right)$ in a monomer/catalyst ratio of 5,000 (w/w). Previous studies demonstrated that this monomer/catalyst ratio produced higher yields and greater molar mass values [21].

Figure 1 shows the ${ }^{1} \mathrm{H}-\mathrm{NMR}$ spectra of PLDLA-TMC. The signals found in the terpolymer ${ }^{1} \mathrm{H}-\mathrm{NRM}$ were practically the same as those for the poly(L-lactide-co-D,L lactide) copolymer and differed at only two points that are characteristic of TMC, that is, $\delta 2.05 \mathrm{ppm}\left(\mathrm{CH}_{2}-\mathrm{TMC}\right)$ and $\delta 4.24 \mathrm{ppm}$ $\left(\mathrm{OCH}_{2}\right.$-TMC) [22]. In the copolymer spectrum (data not shown), a multiplet at 5.12-5.24 ppm was assigned to the $\mathrm{CH}$ (b) proton, while the quartet at $1.55-1.59 \mathrm{ppm}$ was assigned to the protons $\mathrm{CH}_{3}$ (a) [23]. In the case of PLDLA-TMC, the triplet at $2.05 \mathrm{ppm}$ was assigned to the protons $\mathrm{CH}_{2}$ (c), while the triplet at 4.24 was assigned to $\mathrm{OCH}_{2}$ (d).

The ${ }^{13} \mathrm{C}$-NMR spectrum (Figure 2 ) showed lactide units at $16.6\left(\mathrm{CH}_{3}\right), 69.0(\mathrm{CH})$, and $169.6(\mathrm{C}=\mathrm{O}) \mathrm{ppm}$ and TMC units at $27.8\left(\mathrm{CH}_{2}-\mathrm{CH}_{2}-\mathrm{CH}\right), 61.8-64.7\left(\mathrm{CH}_{2} \mathrm{O}\right)$, and 154.8 


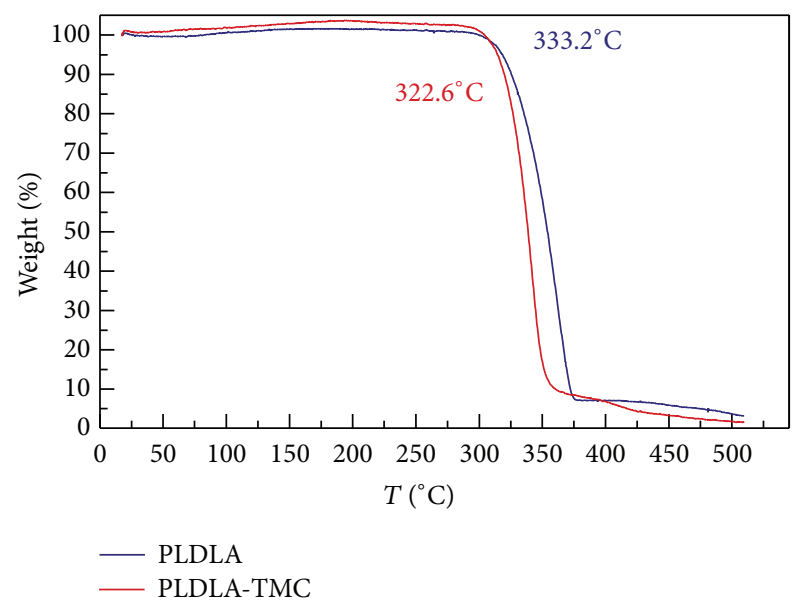

(a)

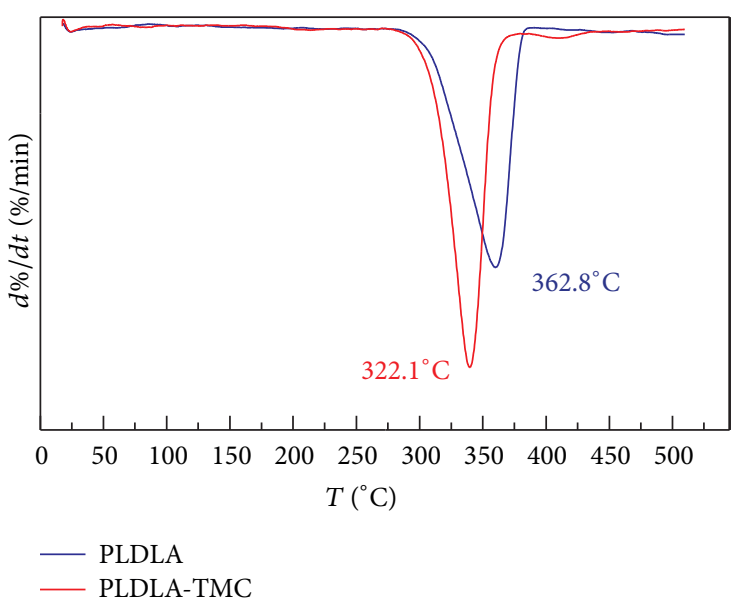

(b)

FIGURE 6: TGA thermograms of PLDLA and PLDLA-TMC scaffolds.

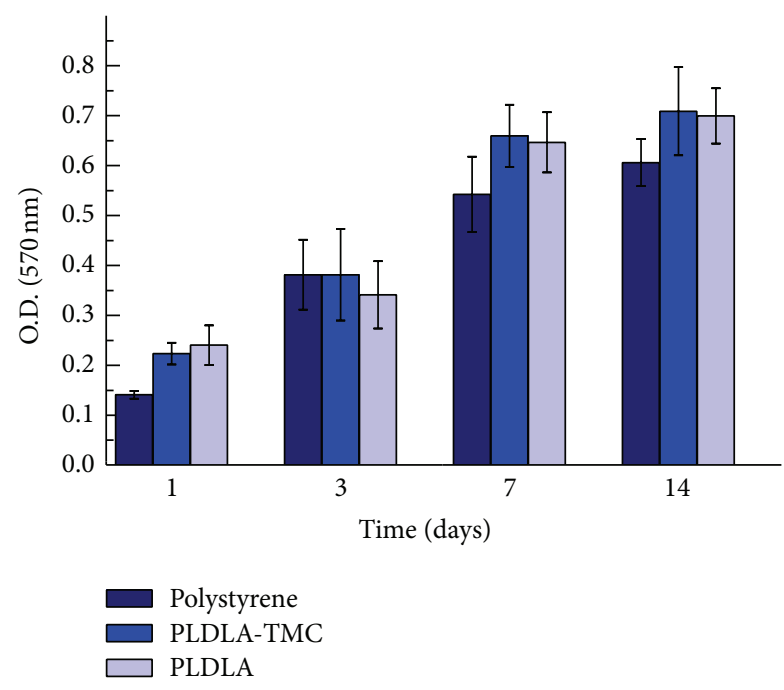

FIgure 7: Viability of SaOS-2 osteoblasts grown on scaffolds. The values are the mean $\pm \mathrm{SD}(n=6)$.

$(\mathrm{C}=\mathrm{O}) \mathrm{ppm}$. These chemical shifts agreed with the findings of Matsumura et al. [24] who synthesized low molar mass $\left(21,000 \mathrm{~g} \mathrm{~mol}^{-1}\right)$ lactide/TMC copolymers using a lipasecatalyzed reaction.

Figure 3 represents PLDLA and PLDLA-TMC infrared spectra and shows no difference when TMC is present. The strongest peaks are found at 1181 and $1746 \mathrm{~cm}^{-1}$ corresponding to $\mathrm{C}-\mathrm{C}$ bonds and carbonyl axial deformation, respectively.

3.2. Scaffold Construction, Morphology, and Thermal Properties. SEM revealed the porous morphology of the scaffold surface (Figures 4(a) and 4(b)) and interior (Figures 4(c) and $4(\mathrm{~d}))$. The pores were irregular in shape and consisted of a mixture of large pores $(\sim 250-500 \mu \mathrm{m}$ in diameter $)$ and small pores $(<100 \mu \mathrm{m})$. Inner side of the scaffold is

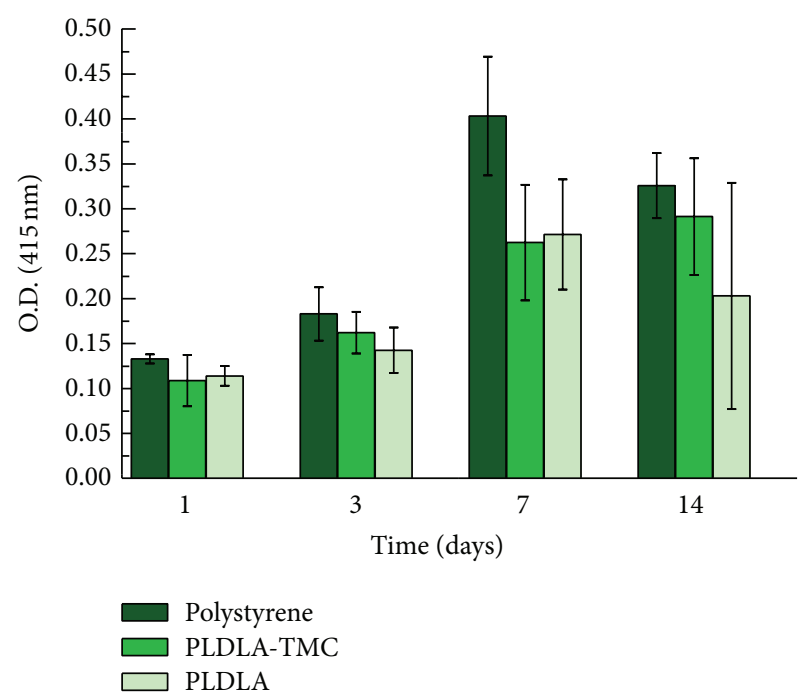

FIGURE 8: Alkaline phosphatase activity of SaOS-2 on scaffolds. Values are expressed as means $\pm \mathrm{SD}, n=6$.

highly porous compared to the scaffold surface (Figures 4(c) and $4(\mathrm{~d}))$. Scaffold porosity and pore size are important features when evaluating biomaterial properties for tissue engineering [25]. An adequate pore size allows cell invasion and tissue ingrowth to surround the local implant while maintaining adequate nutrient transfer; however, there is some controversy regarding the best pore that favors new bone formation and growth [26-28]. The porosity and pore structure can be controlled by salt weight, particle size, and polymer fraction [25].

The results for the thermal characterization of the scaffolds are shown in Figures 5 (DSC) and 6 (TGA). None of the polymeric scaffolds showed evidence of crystallinity. PLDLATMC was amorphous and DSC thermograms showed a decrease in the glass transition temperature $\left(T_{\mathrm{g}}\right)$ of PLDLATMC $\left(51.7^{\circ} \mathrm{C}\right)$ compared to PLDLA $\left(57.9^{\circ} \mathrm{C}\right)$ (Figure 5). 
Similar tendencies were observed for the $T_{\mathrm{g}}$ values for poly(L-lactide-co-TMC) and poly(D,L lactide-co-TMC) [24]. Davachi et al. [29] showed that an increase in the TMC content of poly(lactide-TMC-glycolide) resulted in a decrease in the glass transition temperature. Since the crystalline phase is poorly accessible to water and other permeants, the presence of crystallinity reduces polymer permeability and the rate of biodegradation by chain scission because of a decrease in accessible hydrolysable bonds. With regard to the use of these polymers for biomedical applications, it is worth remembering that crystalline debris formed during degradation may cause an undesired late inflammatory response, thereby negatively influencing tissue growth and normal function [30]. Hence, little or no crystallinity is desirable [31].

The thermal stability of PLDLA-TMC was measured with a thermogravimetric analyzer (TGA). Figure 6 shows typical TGA traces of weight loss as a function of temperature.

This analysis showed that both polymers decomposed in a single-stage degradation and that the addition of TMC reduced the polymer thermal stability; that is, the addition of TMC to L/D,L-lactide resulted in greater degradation of the polymer. The onset temperature of PLDLA decreased from $333.2^{\circ} \mathrm{C}$ to $322.6^{\circ} \mathrm{C}$ when TMC was present. The maximum decomposition temperature of PLDLA was $362.8^{\circ} \mathrm{C}$, whereas that of PLDLA-TMC was $342.1^{\circ} \mathrm{C}$.

3.3. Osteoblast Cell Culture on Scaffolds. The MTT assay showed that the viability of SaOS-2 osteoblasts increased with time (Figure 7), an indication of cell proliferation on the porous scaffolds. The presence of TMC in PLDLA did not affect cell viability compared to scaffolds containing only PLDLA. After 1 and 7 days, cells grown on PLDLA and PLDLA-TMC scaffolds showed greater viability than those grown in control wells $(P<0.05)$. After 14 days, only cells grown on PLDLA-TMC scaffolds had greater viability than control cells $(P<0.05)$. SaOS-2 proliferation ceased at 7 days since the viability was similar at 7 and 14 days.

Early osteoblastic differentiation was demonstrated by the ALP activity of SaOS-2 cells (Figure 8). There was no significant difference in the ALP activities of PLDLA and PLDLA-TMC scaffolds. The ALP activity increased from days 1 and 3 to days 7 and $14(P<0.05)$.

Stein and Lian [32] identified two stages of osteoblast differentiation, namely, proliferation during the first 7-14 days and the secretion of extracellular matrix proteins and production of early differentiation markers, such as ALP, from day 7 onwards. ALP belongs to a group of membranebound glycoproteins involved in the deposition of minerals on extracellular matrix molecules [33].

\section{Conclusion}

Poly(L-co-D,L-lactide-co-trimethylene carbonate) (PLDLATMC) was synthetized by ring-opening bulk polymerization of the monomers, using stannous octanoate as catalyst. Thermal analysis showed that the presence of TMC reduced the glass transition temperature and decreased the polymer thermal stability. The scaffolds had a porous morphology that was conducive to cell growth, as shown in the viability and proliferation of SaOS-2 osteoblasts. The detection of alkaline phosphatase activity demonstrated that the cells retained their osteoblast phenotype. Thus, PLDLA-based devices are potentially useful for bone tissue engineering.

\section{Conflict of Interests}

The authors declare that there is no conflict of interests regarding the publication of this paper.

\section{Acknowledgments}

The authors thank FAPESP (Fundação de Amparo à Pesquisa do Estado de São Paulo, Grant no. 2010/15065-7) for financial support and the Scanning Electron Microscopy Laboratory (LabMEV) of the State University of Campinas (UNICAMP) for providing access to their equipment.

\section{References}

[1] J. A. Baddour, K. Sousounis, and P. A. Tsonis, "Organ repair and regeneration: an overview," Birth Defects Research C: Embryo Today, vol. 96, no. 1, pp. 1-29, 2012.

[2] J. M. Holzwarth and P. X. Ma, "Biomimetic nanofibrous scaffolds for bone tissue engineering," Biomaterials, vol. 32, no. 36, pp. 9622-9629, 2011.

[3] B. Demirbag, P. Y. Huri, G. T. Kose, A. Buyuksungur, and V. Hasirci, "Advanced cell therapies with and without scaffolds," Biotechnology Journal, vol. 6, no. 12, pp. 1437-1453, 2011.

[4] A. C. Motta and E. A. R. Duek, "Synthesis, characterization and "in vitro" degradation of PLLA," Polímeros, vol. 16, no. 1, pp. 2632, 2006.

[5] L. S. Nair and C. T. Laurencin, "Polymers as biomaterials for tissue engineering and controlled drug delivery," Advances in Biochemical Engineering/Biotechnology, vol. 102, pp. 47-90, 2006.

[6] D. J. Darensbourg, W. Choi, O. Karroonnirun, and N. Bhuvanesh, "Ring-opening polymerization of cyclic monomers by complexes derived from biocompatible metals. Production of poly(lactide), poly(trimethylene carbonate), and their copolymers," Macromolecules, vol. 41, no. 10, pp. 3493-3502, 2008.

[7] B. Buchholz, "Analysis and characterization of resorbable DLlactide-trimethylene carbonate copolyesters," Journal of Materials Science: Materials in Medicine, vol. 4, no. 4, pp. 381-388, 1993.

[8] U. A. Stock and J. P. Vacanti, “Tissue engineering: current state and prospects," Annual Review of Medicine, vol. 52, pp. 443-451, 2001.

[9] Y. Wang, G. A. Ameer, B. J. Sheppard, and R. Langer, "A tough biodegradable elastomer," Nature Biotechnology, vol. 20, no. 6, pp. 602-606, 2002.

[10] I. Engelberg and J. Kohn, "Physico-mechanical properties of degradable polymers used in medical applications: a comparative study," Biomaterials, vol. 12, no. 3, pp. 292-304, 1991.

[11] D. W. Grijpma, R. D. A. van Hofslot, H. Supèr, A. J. Nijenhuis, and A. J. Pennings, "Rubber toughening of poly(lactide) by blending and block copolymerization," Polymer Engineering and Science, vol. 34, no. 22, pp. 1674-1684, 1994. 
[12] E. Ruckenstein and Y. Yuan, "Molten ring-open copolymerization of L-lactide and cyclic trimethylene carbonate," Journal of Applied Polymer Science, vol. 69, no. 7, pp. 1429-1434, 1998.

[13] A. R. Katz, D. P. Mukherjee, A. L. Kaganov, and S. Gordon, "A new synthetic monofilament absorbable suture made from polytrimethylene carbonate," Surgery, Gynecology \& Obstetrics, vol. 161, no. 3, pp. 213-222, 1985.

[14] T. Garg, O. Singh, S. Arora, and R. S. R. Murthy, "Scaffold: a novel carrier for cell and drug delivery," Critical Reviews in Therapeutic Drug Carrier Systems, vol. 29, no. 1, pp. 1-63, 2012.

[15] J. D. Kretlow, L. Klouda, and A. G. Mikos, "Injectable matrices and scaffolds for drug delivery in tissue engineering," Advanced Drug Delivery Reviews, vol. 59, no. 4-5, pp. 263-273, 2007.

[16] A. Yousefi, C. Gauvin, L. Sun, R. W. DiRaddo, and J. Fernandas, "Design and fabrication of 3D-plotted polymeric scaffolds in functional tissue engineering," Polymer Engineering and Science, vol. 47, no. 5, pp. 608-618, 2007.

[17] E. Chevalier, D. Chulia, C. Pouget, and M. Viana, "Fabrication of porous substrates: a review of processes using pore forming agents in the biomaterial field," Journal of Pharmaceutical Sciences, vol. 97, no. 3, pp. 1135-1154, 2008.

[18] P. K. D. V. Yarlagadda, M. Chandrasekharan, and J. Y. M. Shyan, "Recent advances and current developments in tissue scaffolding," Bio-Medical Materials and Engineering, vol. 15, no. 3, pp. 159-177, 2005.

[19] S. H. Barbanti, A. R. Santos Jr., C. A. C. Zavaglia, and E. A. R. Duek, "Porous and dense poly(L-lactic acid) and poly(D,Llactic acid-co-glycolic acid) scaffolds: in vitro degradation in culture medium and osteoblasts culture," Journal of Materials Science: Materials in Medicine, vol. 15, no. 12, pp. 1315-1321, 2004.

[20] S. H. Barbanti, A. R. Santos Jr., C. A. C. Zavaglia, and E. A. R. Duek, "Poly( $\varepsilon$-caprolactone) and poly(D,L-lactic acid-coglycolic acid) scaffolds used in bone tissue engineering prepared by melt compression-particulate leaching method," Journal of Materials Science: Materials in Medicine, vol. 22, no. 10, pp. 2377-2385, 2011.

[21] A. C. Motta and E. A. R. Duek, "Synthesis and characterization of the copolymer poly (L-co-D,L lactic acid)," Polímero, vol. 17, no. 2, pp. 123-129, 2007.

[22] D. Pospiech, H. Komber, D. Jehnichen et al., "Multiblock copolymers of L-lactide and trimethylene carbonate," Biomacromolecules, vol. 6, no. 1, pp. 439-446, 2005.

[23] K. A. M. Thakur, R. T. Kean, E. S. Hall, M. A. Doscotch, and E. J. Munson, "A quantitative method for determination of lactide composition in poly(lactide) using ${ }^{1} \mathrm{H}$ NMR," Analytical Chemistry, vol. 69, no. 21, pp. 4303-4309, 1997.

[24] S. Matsumura, K. Tsukada, and K. Toshima, "Novel lipasecatalyzed ring-opening copolymerization of lactide and trimethylene carbonate forming poly(ester carbonate)s," International Journal of Biological Macromolecules, vol. 25, no. 1-3, pp. 161-167, 1999.

[25] X. Zhao, X. Li, Y. Kang, and Q. Yuan, "Improved biocompatibility of novel poly(L-lactic acid)/ $\beta$-tricalcium phosphate scaffolds prepared by an organic solvent-free method," International Journal of Nanomedicine, vol. 6, pp. 1385-1390, 2011.

[26] O. Gauthier, J. Bouler, E. Aguado, P. Pilet, and G. Daculsi, "Macroporous biphasic calcium phosphate ceramics: influence of macropore diameter and macroporosity percentage on bone ingrowth," Biomaterials, vol. 19, no. 1-3, pp. 133-139, 1998.

[27] K. A. Hing, S. M. Best, and W. Bonfield, "Characterization of porous hydroxyapatite," Journal of Materials Science: Materials in Medicine, vol. 10, no. 3, pp. 135-145, 1999.
[28] A. G. Mikos, G. Sarakinos, M. D. Lyman, D. E. Ingber, J. P. Vacanti, and R. Langer, "Prevascularization of porous biodegradable polymers," Biotechnology and Bioengineering, vol. 42, no. 6, pp. 716-723, 1993.

[29] S. M. Davachi, B. Kaffashi, J. M. Roushandeh, and B. Torabinejad, "Investigating thermal degradation, crystallization and surface behavior of l-lactide, glycolide and trimethylene carbonate terpolymers used for medical applications," Materials Science and Engineering C, vol. 32, no. 2, pp. 98-104, 2012.

[30] R. R. M. Bos, F. B. Rozema, G. Boering et al., "Degradation of and tissue reaction to biodegradable poly(L-lactide) for use as internal fixation of fractures: a study in rats," Biomaterials, vol. 12, no. 1, pp. 32-36, 1991.

[31] A. P. Pêgo, A. A. Poot, D. W. Grijpma, and J. Feijen, "Physical properties of high molecular weight 1,3-trimethylene carbonate and D,L-lactide copolymers," Journal of Materials Science: Materials in Medicine, vol. 14, no. 9, pp. 767-773, 2003.

[32] G. S. Stein and J. B. Lian, "Molecular mechanisms mediating proliferation/differentiation interrelationships during progressive development of the osteoblast phenotype," Endocrine Reviews, vol. 14, no. 4, pp. 424-442, 1993.

[33] A. Polini, D. Pisignano, M. Parodi, R. Quarto, and S. Scaglione, "Osteoinduction of human mesenchymal stem cells by bioactive composite scaffolds without supplemental osteogenic growth factors," PLoS ONE, vol. 6, no. 10, Article ID e26211, 2011. 

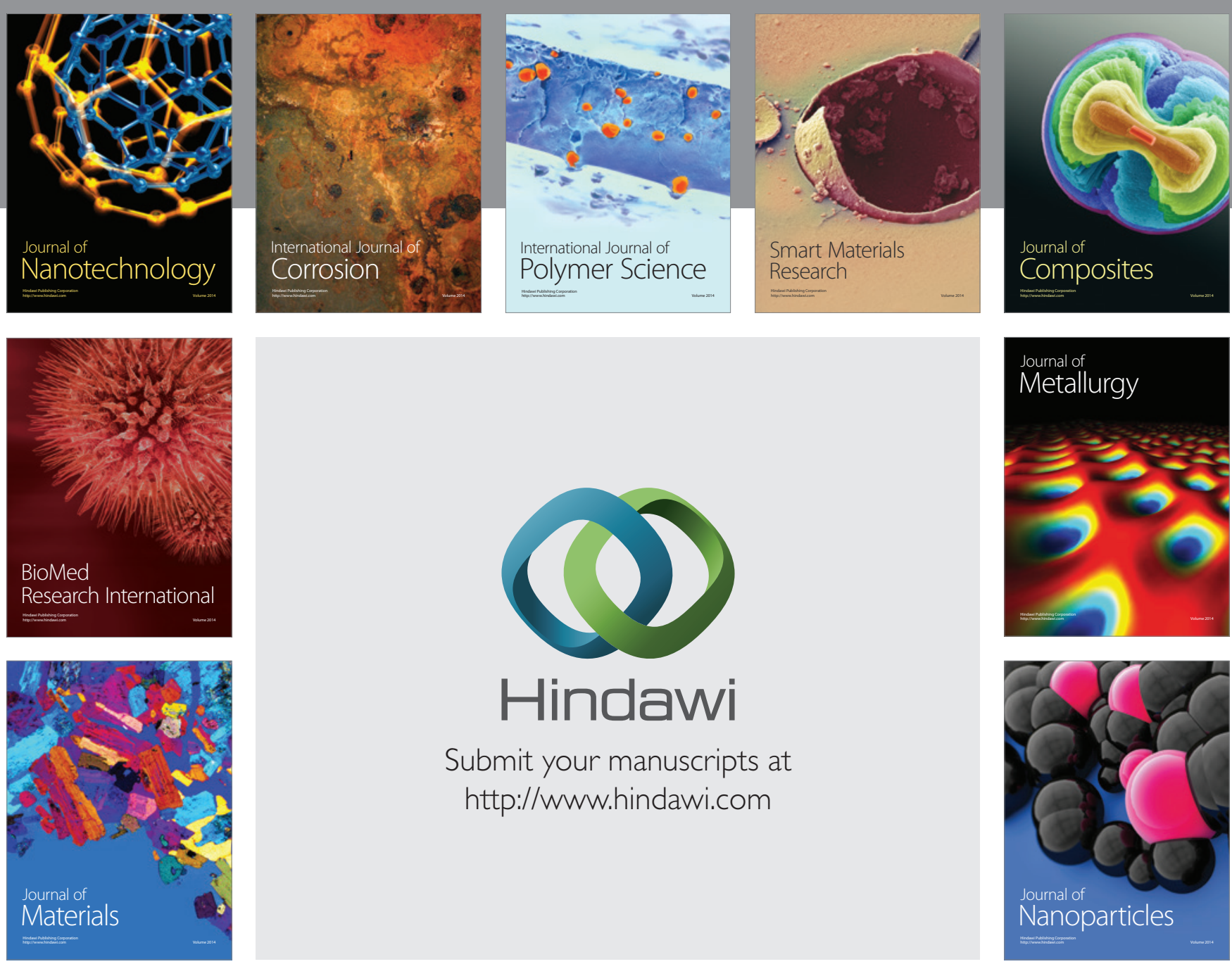

Submit your manuscripts at http://www.hindawi.com
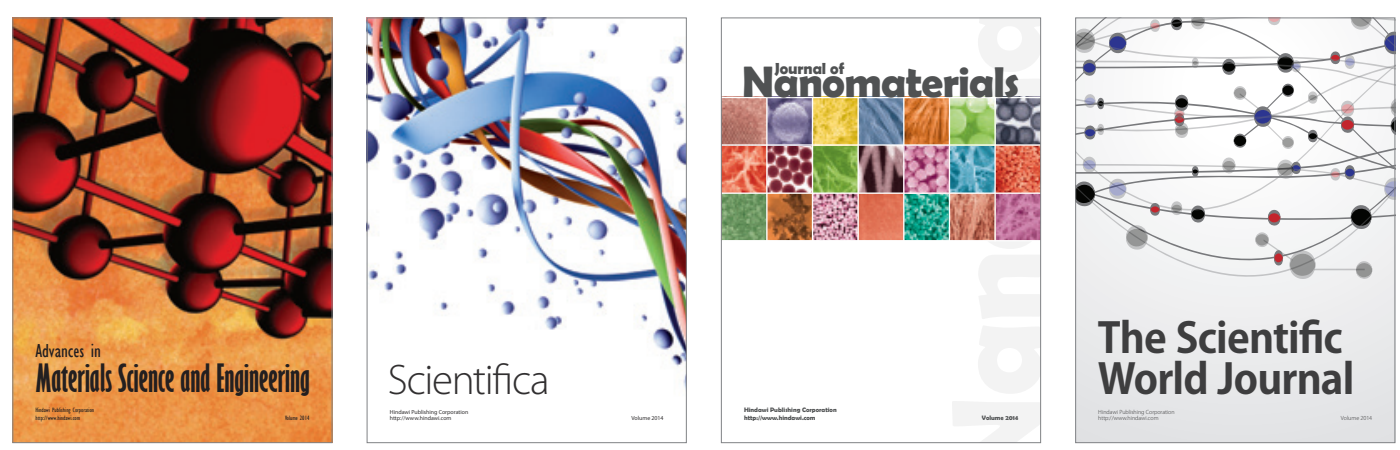

\section{The Scientific World Journal}
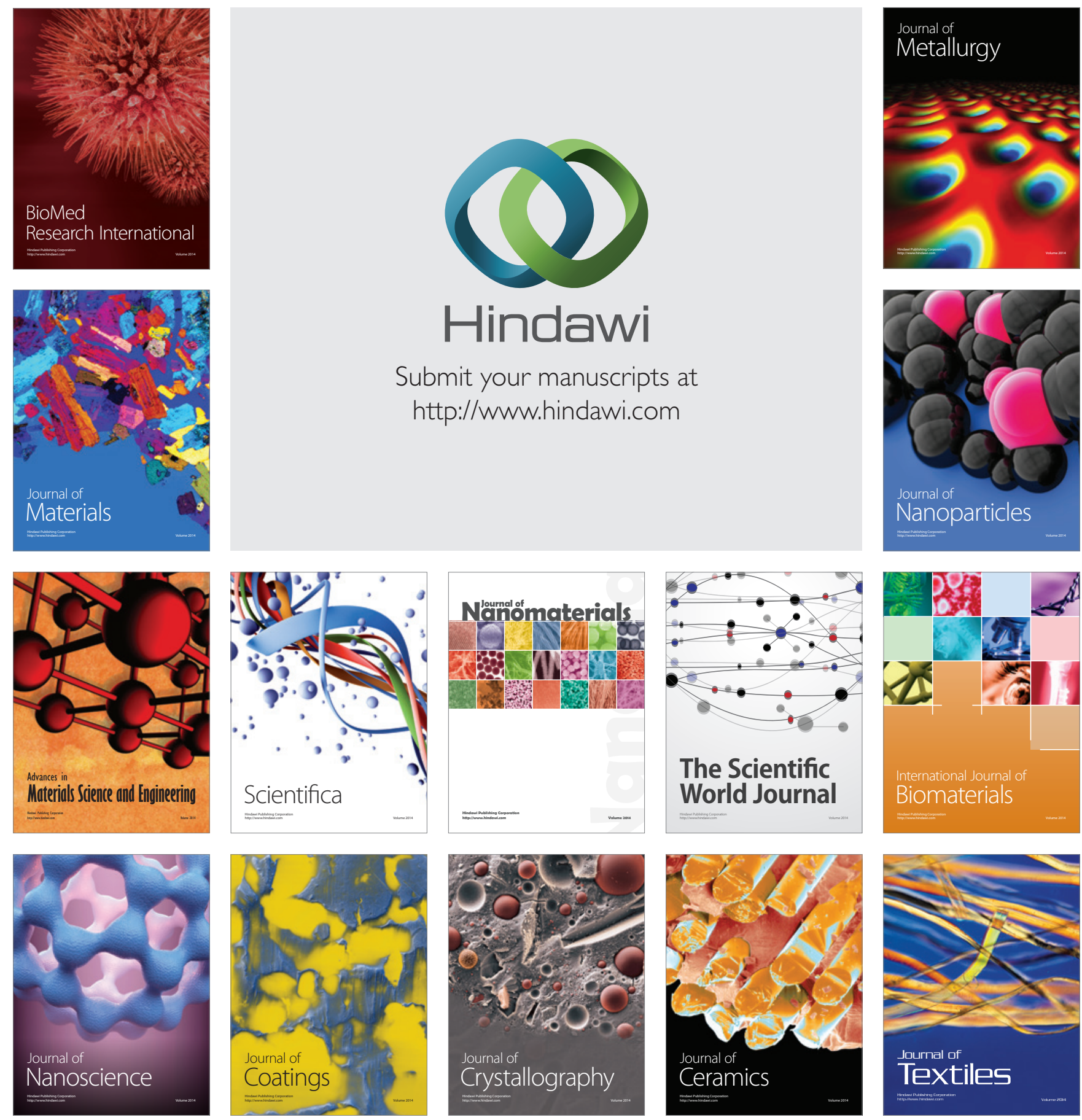